\title{
Game of Thrones as a Gothic Horror in Quality Television
}

\author{
Amanda Rutherford and Sarah Baker \\ Auckland University of Technology (New Zealand) \\ E-mails: amanda.rutherford@aut.ac.nz, sarah.baker@aut.ac.nz
}

\begin{abstract}
Quality television at its heart is designed to reward sustained viewing and involvement on the part of the audience. It has distinctive visual styles, serial characters and storylines and a filmic quality, all of which is evident in Game of Thrones (2011-2019). This article discusses how the scale and cinematic production values of quality television, adds value to the Game of Thrones series through the enhancement and articulation of the Gothic horror.
\end{abstract}

Keywords. Game of Thrones, Gothic horror, fantasy, quality television, violence.

Game of Thrones (created by David Benioff and D. B. Weiss, 2011-2019) is a prime example of quality television and a phenomenal worldwide success, featuring cinematic staging, complex narratives and diverse multi-layered roles. Filled with elements of Gothic horror, which includes sinister power struggles, extreme torture, gratuitous violence and an impending apocalyptic event, the audience is transposed into the world of Westeros, where contemporary cultural issues and anxieties can be examined. In this article, we argue that the extreme popularity of Game of Thrones confirms that there is a growing global demand for programmes that explore and fuel an ever-increasing fascination with violence, horror and torture, utilizing quality television as the mode of delivery to push the boundaries of horror to new levels. According to Stacey Abbott, "television horror has always been a thriving part of TV" $(2012,25)$ and this series mixes horror with a Gothic historical-mythical fantasy setting to create a violent world where acts of cruelty, torture and pain are normalized as part of the society of the time. Game of Thrones also combines genre hybridity, self-reflexivity and intertextuality (Fuller 2013). Through the historical setting, the series utilizes the brutality and gore associated with acts of war as a platform for horror and destruction. 
Simultaneously however, the narratives portray a high level of Gothic intimacy presented in terms of the close interactions between individual characters and story arcs. This is witnessed for example, through the cruel and sadistic acts by Joffrey Baratheon upon others, or the depiction of the extreme torture bestowed upon Theon Greyjoy by Ramsay Bolton. The programme juxtaposes scale and violence with snapshots of intense physical and psychological torture.

The development of quality television in the twenty-first century has brought about some interesting generic relationships because of its tendency to break established rules and to utilize contentious subject matters to draw audiences (Thompson 1997). One of these developments can be observed in the alignment that quality television has formed with horror and the Gothic, where the bar on conventional limits of fear and terror in television is redefined. Graphic horror is now found in television series such as Vikings (Michael Hirst 2013-) or Spartacus (Stanley Kubrick 2010-2013) for example, where the historical background further provides a sense of the Gothic through place and time. Lawson (2013) suggests "it used to be that viewers knew what to expect from a BBC drama, or an ITV comedy, but increasingly the lines are blurring and that's no bad thing." In this respect, the genres in television have shifted stylistically and thematically, and Lawson credits this change to "the rise of hybrid genres, influenced by US independent cinema and cable TV in which a joke can lead to a death, or viceversa" (Lawson 2013). Therefore, this article will explore how Gothic horror has become the means through which HBO continues to push the boundaries of quality television by repeatedly transgressing lines of acceptability and social taboos, broadcast on a global stage.

From the 1980s to the 2000s television changed to a multi-channel environment, but with the arrival of subscription television like HBO and others the same need to keep advertisers happy did not exist. Without the same regulation as network TV, subscription television was able to provide edgier and more provocative programmes. The content produced could push the boundaries and Game of Thrones is a prime example of this change with strong horror themes and multifaceted storylines. No expense is spared to rain layers upon layers of complex storylines and variations of the horror genre, depicting all conceivable representations of blood, torture and pain on the screen. We examine the way these boundaries are stretched, and how Quality television serves as the facilitator to the development of the Gothic horror genre, through its portrayal in Game of Thrones. 


\section{Game of Thrones as Global Quality TV}

Game of Thrones first aired in 2011 through HBO's American cable channel, with the first season sold to numerous subscription and television channels across the world. Its success as a cable programme mirrors that of AMC's zombie apocalypse series The Walking Dead (Billy Gierhart, Ernest R Dickerson, Frank Darabont, Guy Ferland, Gwyneth Horder-Payton, Michelle MacLaren, Phil Abraham, and Stakka Bo 2010-) which premiered in 2010 and by season five was a ratings sensation, pulling in 17.3 million viewers (King 2015), making it the most watched show in cable television history at the time. Game of Thrones had similarly become the largest "hit" for HBO by 2014, whilst simultaneously amassing the largest global piracy record (Lotz 2017). This inspired HBO to reconsider the release options for season five, and by working with 170 markets across the world, they managed a simultaneous release across the globe (Lotz 2017). The popularity of this series has seen it enter mainstream popular referencing, and though quality television was originally believed to be a niche audience phenomenon, the series has reached massive levels of global audiences. The show no longer assumes limited appeal to specific target markets and brings unparalleled attention to the horror genre on television. In 2011, same day viewership was at 2.51 million per episode for season one, increasing substantially in season six to 7.72 million. By season seven, the viewership had risen to 12.1 million (Home Box Office), with the final episode of season seven drawing 16.5 million viewers, as it aired across the globe, "making it the most-watched episode in series history" (Otterson 2017). When factoring in delayed viewing across all platforms, season seven averages 30.6 million viewers globally (Koblin 2017). This figure has increased to 32 million by May 2019 after release of Season eight, and according to HBO, season eight viewership is at 44.2 million per episode (Porter 2019).

The large ensemble cast in Game of Thrones allows for multi-layered storylines and more controversial subject matters to be discussed, whilst being comparable to a filmic experience. Delivery is aimed at niche markets, with varying platforms on which to watch the products, and as such these paid subscription channels are not curtailed by the regulations of the broadcasting television standards (Fuller 2013). This means that Game of Thrones can produce narratives which are contentious and edgy, pushing the accepted norms of television, including scenes of extreme horror and torture, to cater for an ever-increasing horrorconsuming, horror-aware audience. 
Cardwell says that Quality Television pivots on "an intense level of audience appreciation" and "fast-paced style" $(2007,26)$. This creates a raised level of engagement, encouraging the viewers to interpret and critique the work, and to evaluate it. Game of Thrones has maximized the concept of distinguishable visual aesthetics by combining the medieval placement in time, with ancient customs and castles, weapons and battles, with a fantasy world where dragons, giants, White Walkers and the Children of the Forest are meshed and entwined as one workable space in time. This has given the creators the opportunity to layer and utilize their canvass to "portray massive destruction and virtual realities on the screen" (Ostwalt 2000, 14), surpassing previous television boundaries by destabilizing the portrayal of traditional television horror, and recreating fear as a high culture form of popular entertainment. Themes are projected of allencompassing Gothic horror through narratives of sinister power struggles, mass killings and war, patriarchal hierarchies empowered by fear, gruesome tortures and rapes, which culminate in the threat of the White Walkers - the reanimated dead - and the total annihilation and destruction of Westeros in an apocalyptic event. This Gothic mode is used not only to deliver on the themes such as death, destruction, horror and brutality, but more importantly as an uncanny, yet highly relatable measure and facilitator of expression for the dire times in which contemporary society lives today. Spooner suggests that "Gothic texts offer a means of reflecting, expressing or processing already existing anxieties and traumas in the 'real' world" $(2017,11)$, and as such this Gothic platform is well-utilized to spring-board these dark tropes and feelings of being inadequate, anxious or in despair, while conceptualizing the horror of issues and events we do not adequately investigate in modern society.

It is useful to contextualize this programme in a discussion of the horror genre in contemporary television. Jowett and Abbott (2012) argue that television scholars tend to categorize the production of television horror into three broad periods TV1 (roughly 1959-1975), TV II (1975-the 1990s), and TVIII (from the 1990s onwards). Game of Thrones, as a horror within the current period, is thus defined as television that has moved beyond its reputation as "mainstream, mass entertainment aimed at the lowest common denominator" $(2012,10)$, into the realm of quality television of a higher culture value than seen before in television. Similar trends are seen in other successful quality horror television series like The Walking Dead, for example, as although the programme remains focused on the individuals that have survived the zombie apocalypse, "this is not at the expense of graphically depicted decaying bodies, zombies eating human flesh 
and humans exterminating zombies. This commitment to delivering the plot and spectacle typical of a cinematic zombie film in long-running serial format is the 'something more' drawing audiences to the series" (Jowett and Abbott 2012, 12).

Television horror has changed and is frequently seen to take flagship status on cable networks, with quality television programmes like True Blood, The Walking Dead and Game of Thrones placed front and centre of their schedules. These shows focus on representing "the materiality of the body and the visual display of its destruction" (Creed 1995, 128), effectively heightening audience popularity and engagement. There are numerous examples of the destruction of the body in Game of Thrones with its realistic and pronounced horror and destruction of the body, including the "crowning" of Viserys with a molten gold helmet, the poisoning of Joffrey, beheadings and numerous brutal murders. Though similar in its production values to other quality horror television programmes, that encapsulate Gothic themes of isolation, alienation and disease, to name a few, Game of Thrones includes a unique historical setting in time, placing it firmly within the early Gothic era, and its multi-layered character narratives transpose the audience into the period where barbaric customs reinforce the horror that takes place.

Within the dense narratives that take place in Game of Thrones there are several additional tropes of the Gothic in the series, including the Gothic romance. Often the heroines, like Sansa Stark, are tortured by an overpowering patriarch or sadistic male. For example, she is forced to marry Ramsay Bolton against her will, raped and tortured, and mostly used as a pawn in the play between powerful families. Another Gothic theme is that of the protagonist as hero and anti-hero. In Game of Thrones confusion arises between which of the characters are good or evil as their narratives twist throughout the storylines. Many characters are truly honourable and courageous, but this often changes, and the individuals lose status and/or support. Stannis Baratheon, for example, held the best claim to rule over Westeros as the eldest son of Robert. He was held in high regard by Ned Stark and was portrayed as a loyal servant to the throne, however, in a desperate attempt to lead he offered his own daughter to be burnt alive. Stannis Baratheon is one of the characters, who serve to blur the lines between the hero and antihero, like that of Tyrion and Jaime Lannister, Varys, Petyr Baelish and Arya Stark. Emotions stirred by these characters, whether they be positive or negative are intense, and sometimes full of terror.

Henry Giroux suggests that the "public pedagogy of entertainment includes extreme images of violence, human suffering and torture splashed across giant movie screens, some in 3D, offering viewers every imaginable portrayal of violent 
acts, each more shocking and brutal than the last" $(2012,263)$. He explains that there is a growing public interest in sadism and death acts. This has resulted in the need for film and television to constantly turn up the heat, so to speak, on increasingly graphic and violent acts of horror, to retain audiences. The Game of Thrones producers have embraced this public interest and strive to challenge entertainment and television norms by depicting extreme violence and acts of torture, traditionally found in cinema, on the television screen. Under the umbrella term of quality television, the cinematic experience of horror is brought to television, producing episode after episode of exaggerated violence that Giroux (2012) explains is a direct result of the audience interest to witness more and more explicit and dark themes, as forms of entertainment. The extreme popularity of Game of Thrones confirms a global fascination with violence, horror and torture.

HBO's success is based on viewership and subscriptions, making it paramount to introduce material that will be considered innovative and edgy. They "lavish more money on the production of their drama series than any of the broadcast networks can possibly afford" (Anderson 2008, 35), with costs running in the range of $\$ 6$ million per episode for season one ${ }^{1}$ and is believed to cost over $\$ 15$ million per episode for season eight (Shepherd 2017). At the time of its broadcast, Game of Thrones dominated popular culture film and television conversation. Research made by Parrot Analytics, found that Game of Thrones was the most popular television series worldwide - across all social media platforms, blogging and illegal pirating for 2017, with an average daily audience demand of 11.28 million (Nederdog 2017).

\section{Cinematic Experience}

The horror genre in television has been transformed and incorporated into a cinematic quality television experience, which can be seen for example in the episode The Battle of the Bastards (6.9). We argue that the combination of the cinematic quality with the high level of graphic violence in some ways contradicts the negativity that has been associated with slasher or graphic violence before. The quality of the filming and realism for example links the gore, horror and quality aspects together. This episode commences with Jon Snow and Ramsay Bolton meeting on the battlefield, with negotiations of surrender from either

1 See: Emmie Martin: Here's how much it costs HBO to produce one episode of Game of Thrones (2017. August 6), https://www.cnbc.com/2017/08/04/it-costs-millions-to-produce-one-episodeof-hbos-game-of-thrones.html. Last accessed 09. 10. 2021. 
side proving fruitless. Ramsay is known in the series for being the sadistic "bastard," projecting dread and horror through his torturous acts, and Jon Snow is believed to be the bastard son of Eddard Stark. Polan says that horror films are continuously showcasing horror as "a part of us, caused by us" $(2004,143)$, indicating that it is the actual individuals, who are the creators of the horrors experienced, through their personal desires such as the controlling of others or in their pursuit of power. Horror here can also act as a metaphor for the violence and brutal acts that people commit amid political struggles, and not unlike narratives seen in Spartacus or Vikings. This is seen when Ramsay for example, has taken over the Stark home of Winterfell, and has abused and raped Jon's sister Sansa, and holds his brother Rickon Stark prisoner. The battle begins with a vast, deep focus panoramic shot of the outskirts of the Winterfell grounds. The camera then scans across the impressive set to capture the view of the army of Jon Snow with archers in front, followed by rows of cavalry and then hundreds of foot soldiers behind. Banners are displaying the sigils of each clan present, plus the Wildlings (people of the North) and a giant.

Botting explains that "the macabre repertoire of terror is designed to have disturbing effects on characters' [...] imaginations, prolonging the interplay of anticipation and apprehension" (1999, 5), and this is clearly realized within this episode. It is an epic production utilizing a battle format to facilitate another level of horror on a colossal scale. The opening scene sees a wide and deep focus pan across the landscape, zooming into the mid-field view of flayed burning corpses on the battlefield. This epitomizes an "iconographic depiction of the terrors of death" (Cook 2012, 4), with the bodies presented chained upside-down, with the burnt expressions of torture and pain etched into their faces. In this way, the narrative presents horrifying acts of violence which is representative of historic Gothic tradition.

Cardwell says that "it is not that a particular pace or style of camerawork, or level of detail in the mise-en-scène, or type of performance, or particular set of themes, make a programme good - though these things may make it quality television - but that the way in which these things are integrated can create a coherent whole that has stylistic integrity" $(2007,30)$. Ramsay is dragging Rickon by rope behind him, and turns, as if to slit his throat, before releasing him to run to the safety of his brother Jon while he begins to shoot at him with his arrows. This is done to emphasize the evilness of humanity and gives the audience the interpretive means to identify man from monster (Halberstam 2014). The monster Ramsay is toying with Jon to enrage him and lure him into poor judgement, to 
lose concentration on the battle at hand, which is precisely the outcome. In this psychological game of terror, the desperation of Jon is almost tangible, as he charges on his horse to rescue Rickon, whilst the arrows are released one by one. He fails, and Ramsay's arrow pierces Rickon's heart moments before Jon reaches him. This is emphasized through the sound score, heightening the unsettling and ominous experience as it unfolds, and instilling panic and horror. The ensuing battle that occurs presents the entire scene as one of epic proportions. As Jon's horsemen charge into the battle the noise is thunderous, and the ground level filming heightens the experience and realism. The galloping horses are seen in slow motion giving time to absorb each detail of their determination and movement. Giles says that in the horror genre, what "the film industry sells to the viewer is not a material thing but an experience, or promise, of pleasure" $(2004,37)$, and the suspense at this moment is visceral as the audience watches and anticipates every movement to follow.

While cinematic in form in many ways, this battle continues as part of a complex, and networked production system and narrative, and ensures an aesthetic continuity which forms part of the Gothic horror experience of the entire series. Far from traditional cinematic film, this production alters the experience of death within a typical battle format. Ramsay instructs his archers to reign arrows over the battlefield, killing and maiming hundreds of both his and Jon's men. It is this realization that he purposely sacrifices the lives of his own men, that highlights the extent of his evil nature, and confirms that it is the actual acts of horror that are being represented and not the act of the war. There is an unprecedented scale of death as layers upon layers of dead and injured men lie on the ground, creating small hills which soon become a wall of bodies that the soldiers must scramble over, slipping in their blood and bodily fluids, and including sights of the entrails of the dead and still living, writhing in pain. This is synonymous of the Gothic grotesque, where we see "bodies that straddle categories, perhaps covered with effluent substances that render what should be on the inside of the person onto its outside" (Mukherjea 2012, 114). As the battle seems lost for Jon and his men, being surrounded by Ramsay's army, yet another wave of horsemen swoop into the battle in the form of the Petyr Baelish cavalry, who destroy Ramsay's forces from behind and the battle is won for Jon Snow.

Much of the discussion around the rise of quality or prestige television has centred around the role of showrunners and writers who have energized television. In the last decade "the schisms between the small and big screens dwindled. And not merely in the scope of the stories or quality of the scripts: 
never before has television looked so good, from inventive camerawork to glossy lighting" (Nevins 2018). The focus on the affect and aesthetic in this scene is keenly evident and meets the criteria of quality television whilst altering the parameters of how horror is usually displayed in television.

\section{Torture Porn and Complex Narratives}

The complex narratives seen in the HBO cable network series fulfil the parameters of quality television with its "cutting-edge, in-your-face television that employs liberal amounts of sex, violence and swearing as well as serious or adult themes in an artful and stylistic package" (Cherry 2012, 3). These narratives continuously intertwine themselves through the fantasy-medieval setting with the producers proving "unafraid to be confrontational in their writing or in their explicit visuals" (Cherry 2012, 7).

The focus of the series is often on explicit visuals and conventions, which are associated with the horror subgenre torture porn. Jones suggests that "torture porn discourse highlights confusions regarding how taboo is defined" (2013, 2), and that, it is a site of discursive struggle. Torture porn largely focuses upon the spectacle of physical and psychological suffering being inflicted, and in Game of Thrones the characters are frequently seen in confined spaces; being subjected to physical and psychological suffering; or subjected to varying forms of calculated infliction of human cruelty. For example, there are two key characters who torture their victims solely for their own pleasure; King Joffrey and Ramses Bolton. In the Garden of Bones (2.4), prostitutes Ros and Daisy have been called to give sexual pleasure to the new King Joffrey Baratheon, and it becomes apparent that it is not sex that he wants, as he instructs Ros to hit Daisy, then beat her with a belt, and then a stag head sceptre. Torture porn is seen as a sub-category of the horror genre, and has been compared to earlier subgenres, such as slasher and splatter films (Jones 2013). David Edelstein says that "explicit scenes of torture and mutilation were once confined to the old 42nd Street... whereas now they have terrific production values and a place of honour in your local multiplex" (2006). In this respect, torture porn can be seen to constitute itself not only in scenes of physical torture, but in the aesthetics, which bring to the fore tropes of violence, and carry viewers through an unforgettable spectacle. In The Climb (3.6), Ros the prostitute, now gifted to King Joffrey for his pleasure, has been tied to Joffrey's bed and shot several times with his crossbow, culminating with a final arrow into her heart. The pleasure taken from this and the explicit nature 
of this scene shows where aspects of torture porn have slipped into the Game of Thrones narrative and how witnessing such violence on television lures audiences into retained viewership and has grown to become an expectation of the audience. Jones (2013) states that some critics suggest torture porn in the horror genre replaces narrative depth and characterization, however, we argue that this is not the case in Game of Thrones. Whilst at times the sadistic violence together with torture seems the central aspect of the plot, the focus on horror is crucial to the characterization of protagonists like Joffrey and Ramsay and there is a constant weaving between individual characters as well as storylines without loss of quality or the over-arching themes. Consequently, the use of torture brings further layers of depth to the show.

Having discussed the sadistic violence and torture that are central to the plot it is important to consider why such aspects would appeal to an audience. Carrol suggests that "there is something paradoxical about the horror genre. It obviously attracts consumers; but it seems to do so by means of the expressly repulsive" (1990, 159). As Creed writes, "the horror film abounds in images of abjection, foremost of which is the corpse, whole and mutilated, followed by an array of bodily wastes such as blood, vomit, saliva, tears and putrefying flesh” (1995, 253). The horror genre therefore gives pleasure to its audience, but it does this by going into areas that cause distress and displeasure. In other words, the audience feel compelled to watch even if this viewing causes distress. In this regard, horror often deals with the abject, where the audiences' reaction to blood or vomit or dead bodies generates a breakdown in meaning, which is caused by the loss of the distinction between subject and object or self and other. A corpse for example, reminds the viewers of their own materiality (Kristeva, 1982). Thus, much horror works through this mixture of attraction and repulsion.

Game of Thrones is a world of unfolding betrayal, torment, anguish and pain, with only rare and short-lived glimpses into any form of peace, unity or happiness. Ramsay Bolton is a sociopath known for gaining pleasure from extreme torture, and physical as well as mental cruelty. Lowrey and deCordova (2004) say that one of the key experiences of the horror film is the creation of fear and excitement. Ramsay takes immense pleasure in activities such as the terrorizing and hunting of women in the woods with his dogs (4.2); he murdered his father Roose (6.2), then his stepmother Lady Walda and newborn brother, feeding them to his dogs (6.2). Ramsay's physical and psychological torture and subsequent castration of Theon Greyjoy was extreme and unrelenting, as Ramsay turned Theon into his "pet" named Reek, thus emphasizing how "sadism and 
the infatuation with violence have become normalized in a society that seems to take delight in dehumanising itself" (Giroux 2012, 260). Though torturing a character does not necessarily make a film or series torture porn, the legacy of the torture porn subgenre is an increased level of explicit and extreme horror across the genre. The delight that Bolton takes in the level of torture and the positioning of the audience in this arc suggests that this is not just horror, but contains elements of torture porn with the repellent treatment of Greyjoy, and further aligns the audience with torture porn dynamics, watching and enjoying the explicit violence, while also being repulsed by its portrayal.

"When girls or young women enter the plots, the threat of the monstrous bridegroom is primarily sexual" (Warner 1998, 74) as seen on the night of Ramsay's wedding to Sansa. Ramsay takes her to his quarters and has Reek (the name taken by Theon after his subjugation to Ramsay following his castration) watch as he rapes her. Theon weeps as he watches, yet is unable to defend Sansa as he is so afraid of Ramsay. During an interview actor Iwan Rheon (Ramsay) said that Game of Thrones is "a true depiction of the world that we've created... it's true of what happened when this was hypothetically based. And it's true of what's happening today in the world" (Bennion 2016). When studying the horror film, Telotte says that there is a heavy reliance on the "evocation of audience participation", and the "ability to convince us that its threats have some measure of reality about them. They exist within a context of their own making, a world which we, in unspoken agreement, certify as a real, although aberrant, part of our own environment; hence, they represent a threat not just to our existences, but to our very human nature" (Telotte 2004, 23). Ramsay is a monster of modern times, featuring in a complex and almost deranged narrative that fits the remit of quality television, and represents broader social fears and anxieties in a very intimate, Gothic manner.

The show also signals its quality through the way horror tropes become embedded within complex narratives surrounding religion. The series features several varying belief systems, faiths and religions, values and morals, in many instances orchestrated to address contemporary societal problems and issues of the twenty-first century. Within the faux historical context of Game of Thrones, these issues are presented in a barbaric manner at times, yet pertinent to the relevance of the destructive nature of humankind in our world today. In the opening scene of Winter is Coming (1.1), Will finds a group of dead Wildling bodies, dismembered and formed into a gruesome and ritualistic pattern in the snow, with their heads poised upon spikes in the ground. The example of the 
Gothic grotesque body is seen here, "incomplete, lacking in vital parts" (Edwards and Graulund 2013, 2) with multiple pieces of multiple bodies missing. Another pattern is seen in the episode Walk of Punishment (3.3) where a spiral shape is seen made from horse heads and parts and then a similar patterning of the spiralling stones around the sacred Weirwood tree, where a First Man was transformed into the Night King with a dragonglass dagger (Blood of My Blood 6.5). These gruesome spiral shapes left by the White Walkers resemble those found on the hill where Will was beheaded (1.1). Perhaps both humans and White Walkers are worshippers of the same gods, through a transposed memory taken with the transformation of the First Man into the Night King, but the gruesome body parts emphasize for viewers their differing respect for human life.

Dickstein says that the "decline of religion and the increasing secularization of society have given more and more mythical resonance to popular culture, which provides us with binding and common experiences and satisfies some primitive needs. The subcultural material in horror films is one form of this return of the repressed" $(2004,55)$, and the complex spiritualistic narratives in Game of Thrones can be a means of contemplation regarding religious beliefs or theories about the origin of life in contemporary society. In line with the horror genre in general, and the tendency of quality television towards narrative complexity, distinguishing which deities are good is not necessarily clear for the audience. For example, the Lord of Light, worshipped by the priestess Melisandre, is undoubtedly dark. Melisandre receives messages from her god by watching burning flames and performing ritual sacrifices. In Garden of Bones (2.4) she births a demon spirit "shadow" which is used to kill Renly Baratheon, one of the claimants to the Iron Throne. "The actions of witches, sorcerers, demons, and devils provide the rationale for displays of virtuosity on the part of the filmmaker" (Russell 2004, 66) and it is interesting to see the portrayal of Melisandre, advising Stannis Baratheon to burn three prepared leeches, to enable the destruction of his enemies Robb Stark, Balon Greyjoy and Joffrey Baratheon. Hence, this scene displays the narrative complexity commonly seen in quality television programmes and demonstrates that morality in Game of Thrones is not a clear cut or black or white thing. By the end of season six all three men are dead and Melisandre convinces Stannis to sacrifice his daughter Shireen as a gift to her Lord of Light to win in battle. The gruesome burning of his child, however, (The Dance of Dragons 5.9) does not prove successful. This scene is both engrossing and appalling, full of moral ambiguity and confusion. The audience is rendered unable to comprehend that the child will actually be burnt, and expecting that 
the parents will put an end to the travesty. In this respect "scariness has gained ground as pleasure" (Warner 1998, 4), and by the audience engagement HBO is successfully operating its horror on the platform of quality television.

The multi-narrative twists again when Jon Snow, one of the lead characters in Game of Thrones, is murdered by fellow members of the Night's Watch in the final episode of season five (Mother's Mercy 5.10). The "particular notion of hardness and aggressive masculinity has become commonplace in a society in which digestible spectacles of violence are endlessly circulated through proliferating media forms" (Giroux 2012, 263). The men of the Night's Watch epitomize such mediated males as they are dangerous and aggressive men, known through all of Westeros for their horror and crimes. Jon Snow is dead, murdered by his own men of The Wall, and a main protagonist, recognized as the prime candidate for some sort of salvation amid the series' grotesque and violent world, is taken. In a bizarre turn of events Melisandre, the priestess, resurrects Jon Snow after his brutal stabbing (Home 6.2) with the "magic" of her dark Lord. As a result, his aggressive murderers are shown not only as incapable of removing Jon from his position of power and control, but also having inadvertently awarded him an enormous amount of power. These men are later killed by Jon for their betrayal.

There are other forms of faith and witchcraft seen in Game of Thrones and the audience meets the witch Mirri Maz Duur, who advises Daenerys Targaryen that as a "godswife," priestess of the Lhazareen god, she has the power to save the life of her husband by using "blood magic" (Fire and Blood 1.10). In Gothic texts "the witch is a person, usually female, who is responsible for maleficium, evil acts, expressed through charms, portents, curses, the mid-wife who kills or delivers deliberately deformed children” (Russell 2004, 63). Drogo is dying, and Daenerys allows the witch to perform her blood magic by sacrificing the life of his horse, despite fierce opposition from the Dothraki. This blind faith shown by Daenerys is poorly calculated as the witch seeks vengeance for the crimes to her family and a Gothic theme of entrapment and torture emerges as she leaves Khal Drogo alive, but in a seemingly brain-dead state. Furthermore, when Daenerys's baby is born the witch advises her that it was born a monster, full of deformation, and thus speaks to the argument by Russell (2004), where the witch presents a Gothic act of deformed and death in the child, aligning with another common Gothic trope.

The narrative consistently reminds viewers that "winter is coming," a threat to all mankind. It is a period known in their ancient history of great cold, suffering and the almost indestructible White Walkers, who will again threaten extinction of man. "Like much dystopian science fiction, the apocalyptic or post- 
apocalyptic can be interpreted as a Gothic mode, as despite its apparent future setting, it deals not with the development of civilization (as in the majority of science fiction) but with its posited decline and fall, thus creating a situation in which its protagonists constantly live either with the shadow of the past within a hostile present environment, or with the prospect of a dystopic society's imminent collapse" (Lloyd Smith 2004, 164). The over-arching theme of the entire series is not unlike that of Vikings (2013-), where the tale of a long-past harsh and unforgiving period becomes the landscape for violence, torture and a Gothic framed exploration of terror. The threat of an apocalyptic event manifests in season 8, and the reality is that all inhabitants are required to fight against the threat of the White Walkers who are near-impossible to defeat.

\section{Conclusion}

Albeit set against a fantasy backdrop, Game of Thrones is ultimately about betrayal, jealousy and hatred though it is situated in a pseudo-medieval world that incorporates the supernatural as well as historical settings. By combining these elements, Game of Thrones creates a complex world, addressing and exceeding audience expectations of what is defined as quality television. The subscription channels have had a strong presentation of horror within their programmes, using graphic style body horror, and are now once more pushing these boundaries by encapsulating a Gothic mode intertwined with all forms of horror within the narrative. According to Dickstein, "fright and terror have never really been out of style" $(2004,50)$ and it is under this premise that the producers framed the series with combinations of these themes. Game of Thrones combines a distinctive visual style, serial characters and storyline development, and a focus on star performers, while bringing a new level of horror to global audiences. In contrast with series such as Vikings, which share the setting and plotting among characters for the throne, Game of Thrones distinguishes itself by the unrelenting and highly detailed depiction of terror and horror through the series presented as a normal part of everyday life in that time, and the number of parallel multilayered narratives. It is however, the significant level of violence seen in Game of Thrones combined with the aesthetics of quality television that make this a unique benchmark in how the levels of horror and terror have been raised. The combination of horror in its many forms meshed with the aesthetics and narrative format of quality television make this an example of how Game of Thrones has pushed the boundaries of acceptability with regard to genre on television. In so 
doing, the adoption of horror tropes in Game of Thrones has also taken quality television to new levels and set a new benchmark for the expectations of both audiences and producers by normalizing brutality and horror in a Gothic setting, enthralling a global audience in an unprecedented scale, and bringing to the foreground a global appreciation of the horror genre on television.

\section{References}

Abbott, Stacey. 2012. TV Loves Fangs: The Television of HBO Horror. In True Blood: Investigating Vampires and Southern Gothic, ed. Brigid Cherry, 25-38. London: I.B. Tauris.

Anderson, Carolyn. 2008. Producing an Aristocracy of Culture in American Television. In The Essential HBO Reader, eds. Gary R. Edgerton and Jeffrey P. Jones, 23-41. Lexington: University Press of Kentucky.

Bennion, Chris. 2016. Game of Thrones Star Iwan Rheon: "I was dreading Sansa rape scene”,. The Telegraph. Culture TV. https://www.telegraph.co.uk/ tv/2016/04/23/game-of-thrones-star-iwan-rheon-i-was-dreading-sansa-rapescene/. Last accessed 21. 09. 2021.

Botting, Fred. 1999. Gothic. London: Taylor and Francis.

Carroll, Noël. 1990. The Philosophy of Horror: or, Paradoxes of the Heart. New York: Routledge.

Cardwell, Sarah. 2007. Is Quality Television Any Good?: Generic Distinctions, Evaluations and the Troubling Matter of Critical Judgement. In Quality TV: Contemporary American Television and Beyond, eds. Janet McCabe and Kim Akass, 72-80. London: I.B. Tauris.

Cherry, Brigid. 2012. Before the Night is Through: True Blood as Cult TV. In True Blood: Investigating Vampires and Southern Gothic, ed. Brigid Cherry, 3-24. London: I.B. Tauris.

Cook, Jonathan. A. 2012. Poe and the Apocalyptic Sublime: The Fall of the House of Usher. Papers on Language \& Literature vol. 48, no. 1: 3-44.

Creed, Barbara. 1999. Horror and the Monstrous-Feminine: An Imaginary Abjection. In Feminist Film Theory: A Reader, ed. Sue Thornham, 251-266. New York: New York University Press.

Creed, Barbara. 1995. Horror and the Carnivalesque. In Fields of Vision: Essays in Film Studies, Visual Anthropology and Photography, ed. Leslie Devereaux and Roger Hillman, 127-159. Los Angeles: University of California Press. 
Dickstein, Morris. 2004. The Aesthetics of Fright. In Planks of Reason: Essays on the Horror Film, eds. Barry Keith Grant and Christopher Sharrett, 68-87. Oxford: Scarecrow Press.

Edelstein, David. 2006. Now Playing at Your Local Multiplex: Torture Porn. NYMAG.com. http://nymag.com/movies/features/15622/. Last accessed 21. 09. 2021.

Edwards, Justin D. and Graulund, Rune. 2013. Grotesque. Abingdon and New York: Routledge.

Fuller, Sean. 2013. Quality TV: The Reinvention of US Television. Sydney: The University of Sydney.

Giles, Dennis. 2004. Conditions of Pleasure in Horror Cinema. In Planks of Reason: Essays on the Horror Film, eds. Barry Keith Grant and Christopher Sharrett, 49-67. Oxford: Scarecrow Press.

Giroux, Henry. A. 2012. Disturbing Pleasures. Murderous Images and the Aesthetics of Depravity. Third Text vol. 26, no. 3: 259-273.

Halberstam, Judith. 2014. Skin Shows: Gothic Horror and the Technology of Monsters. Durham: Duke University Press.

Jones, Steve. 2013. Torture Porn: Popular Horror After Saw. Basingstoke: Palgrave Macmillan.

Jowett, Lorna and Abbott, Stacey. 2012. TV Horror: Investigating the Dark Side of the Small Screen. London: I.B. Tauris.

King, Chris. 2015. The Walking Dead Breaks Its Own Ratings Records With Its Season 5 Premiere. TVOvermind.com. https://www.tvovermind.com/walkingdead-breaks-ratings-records-season-5-premiere/. Last accessed 21. 09. 2021.

Koblin, John. 2017. Game of Thrones Finale Sets Ratings Record. New York Times. Television. https://www.nytimes.com/2017/08/28/arts/television/game-ofthrones-finale-sets-ratings-record.html. Last accessed 21. 09. 2021.

Lawson, Mark. 2013. The American, Love and Marriage and the Rise of Hybrid TV Genres. https://amp.theguardian.com/tv-and-radio/tvandradioblog/2013/ jun/04/americans-love-marriage-hybrid-genres. Last accessed 21. 09. 2021.

Lloyd Smith, Allan. 2004. Nineteenth-Century American Gothic. In A Companion to the Gothic, ed. David Punter. Malden, Oxford and Sussex: Blackwell Publishers.

Lotz, Amanda. 2017. How Game of Thrones became TV's first global blockbuster. The Conversation. https://theconversation.com/how-game-of-thrones-becametvs-first-global-blockbuster-79820. Last accessed 21. 09. 2021. 
Lowrey, E. and deCordova, R. 2004. Enunciation and the Production of Horror in White Zombie. In Planks of Reason: Essays on the Horror Film, eds. Barry Keith Grant and Christopher Sharrett, 229-264. Oxford: Scarecrow Press.

Kristeva, Julia. 1982. Powers of Horror: An Essay on Abjection. New York: Columbia University Press.

Mukherjea, Ananya. 2012. Mad, Bad and Delectable to Know: True Blood's Paranormal Men and Gothic Romance. In True Blood: Investigating Vampires and Southern Gothic, ed. Brigid Cherry, 109-121. London: I.B. Tauris.

Nevins, Jake. 2018. Aesthetic excellence: how cinematography transformed TV: Directors of photography from Atlanta Transparent and other top shows discuss how they achieve the sensibility of cinema. The Guardian. https:// www.theguardian.com/tv-and-radio/2018/mar/01/tv-that-doesnt-look-liketv-how-cinematography-relit-the-small-screen?CMP=share_btn_link. Last accessed 21. 09. 2021.

Ostwalt, Conrad. E. 2000. Armageddon at the Millennial Dawn. Journal of Religion and Film vol. 4, no. 1. https://digitalcommons.unomaha.edu/jrf/vol4/iss1/4. Last accessed 21. 09. 2021.

Otterson, Joe. 2017. Game of Thrones Season 7 Finale Draws Record 16.5 Million Viewers. Variety, Home, TV, Ratings. https://variety.com/2017/tv/ratings/ game-of-thrones-season-7-finale-ratings-2-1202540601/. Last accessed 21. 09. 2021.

Polan, Dana. B. 2004. Eros and Syphilization: The Contemporary Horror Film. In Planks of Reason: Essays on the Horror Film, eds. Barry Keith Grant and Christopher Sharrett, 193-207. Oxford: Scarecrow Press.

Porter, Rick. 2019. Game of Thrones Series Finale Sets All-Time HBO Ratings Record. The Hollywood Reporter. https://www.hollywoodreporter.com/livefeed/game-thrones-series-finale-sets-all-time-hbo-ratings-record-1212269. Last accessed 21. 09. 2021.

Russell, Sharon. 2004. The Witch in Film: Myth and Reality. In Planks of Reason: Essays on the Horror Film, eds. Barry Keith Grant and Christopher Sharrett, 87-110. Oxford: Scarecrow Press.

Shepherd, Jack. 2017. Game of Thrones season 8 costing HBO \$15 million per episode. Independent. Culture, TV \& Radio, News. https://www.independent. co.uk/arts-entertainment/tv/news/game-of-thrones-season-8-cost-perepisode-a7970311.html. Last accessed 21. 09. 2021.

Spooner, Catherine. 2017. Post-Millennial Gothic: Comedy, Romance and the Rise of Happy Gothic. London. England: Bloomsbury Publishing. 
Telotte, J. P. 2004. Faith and Idolatry in the Horror Film. In Planks of Reason: Essays on the Horror Film, eds. Barry Keith Grant and Christopher Sharrett, 27-49. Oxford: Scarecrow Press.

Thompson, Robert J. 1997. Television's Second Golden Age: From Hill Street Blues to ER. New York: Continuum.

Warner, Marina. 1998. Monsters of our Own Making: The Peculiar Pleasures of Fear. Kentucky: The University Press of Kentucky.

Watson, Amy. 2018. Home Box Office (HBO) - Statistics \& Facts. Statista. Media $\&$ Advertising. Radio, TV $\&$ Film. HBO. https://www.statista.com/topics/4291/ hbo/. Last accessed 21. 09. 2021. 